\title{
Utility of platelet-to-lymphocyte ratio to support the diagnosis of acute deep vein thrombosis
}

\author{
Akut derin ven trombozu tanısının desteklenmesinde trombosit/lenfosit oranının kullanışlığı
}

\author{
Yusuf Velioğlu $(\mathbb{0}$, Ahmet Yüksel 1 \\ Department of Cardiovascular Surgery, Abant Izzet Baysal University Faculty of Medicine, Bolu, Turkey
}

\begin{abstract}
Background: The aim of this study was to investigate whether routine complete blood count parameters such as the mean platelet volume, red cell distribution width, white blood cell and platelet counts, and novel inflammatory biomarkers such as platelet-to-lymphocyte ratio and neutrophil-to-lymphocyte ratio could be used as the predictors of acute deep vein thrombosis.
\end{abstract}

Methods: This retrospective study included a total of 68 patients (29 males, 39 females; mean age 55.2 \pm 1.6 years; range, 22 to 80 years) with acute lower extremity deep vein thrombosis and 34 healthy controls (15 males, 19 females; mean age $52.8 \pm 2.5$ years; range, 21 to 77 years) without acute lower extremity deep vein thrombosis between March 2016 and August 2018. Demographic and clinical characteristics of the participant and laboratory data including complete blood count parameters were recorded. Univariate and multivariate analyses were used to identify significant predictors of deep vein thrombosis.

Results: Demographic and clinical characteristics were similar between the groups. According to the univariate analysis, platelet count and red cell distribution width were found to be significantly higher in the patient group compared to the control group. However, the red cell distribution width was not considered a significant predictor of acute deep vein thrombosis. According to the multivariate logistic regression analysis, the platelet-to-lymphocyte ratio and platelet count were significant predictors of acute deep vein thrombosis.

Conclusion: Our study results show that the platelet-tolymphocyte ratio may be a useful biomarker to support the diagnosis of acute deep vein thrombosis.

Keywords: Acute deep vein thrombosis, complete blood count parameters, platelet count, platelet-to-lymphocyte ratio.

\section{$\ddot{O} Z$}

Amaç: Bu çalışmada, ortalama trombosit hacmi, kırmızı hücre dağılım genişliği, beyaz kan hücresi ve trombosit sayısı gibi rutin hemogram parametreleri ve trombosit/lenfosit oranı ve nötrofil/lenfosit oranı gibi yeni enflamatuvar biyobelirteçlerin akut derin ven trombozunun öngördücüleri olup olmadığı araştırıld1.

Çalışma planı: Bu retrospektif çalışmaya Mart 2016 ve Ağustos 2018 tarihleri arasinda akut alt ekstremite derin ven trombozu olan toplam 68 hasta (29 erkek, 39 kadın; ort. yaş 55.2 \pm 1.6 y1l; dağ $\breve{l l}_{1 \mathrm{~m},} 22-80$ y1l) ve akut alt ekstremite derin ven trombozu olmayan 34 sağlıklı kontrol (15 erkek, 19 kadın; ort. yaş $52.8 \pm 2.5$ yıl; dağılım 21-77 yıl) dahil edildi. Katılımcıların demografik ve klinik özellikleri ve hemogram parametreleri dahil olmak üzere laboratuvar verileri kaydedildi. Derin ven trombozunun anlamlı öngördürücülerini belirlemek için tek değişkenli ve çok değişkenli analizler yapıldı.

Bulgular: Demografik ve klinik özellikler gruplar arasında benzerdi. Tek değişkenli analizde, trombosit sayısı ve kırmızı hücre dağılım genişliği, kontrol grubuna kıyasla, hasta grubunda anlamlı düzeyde yüksek bulundu. Ancak, kırmızı hücre dağ 1 lım genişliği, akut derin ven trombozunun anlamlı bir öngördürücüsü olarak belirlenmedi. Çok değişkenli lojistik regresyon analizine göre, trombosit/lenfosit oran1 ve trombosit sayısı akut derin ven trombozunun anlamlı öngördürücüleri idi.

Sonuç: Çalışma sonuçlarımız, trombosit/lenfosit oranının akut derin ven trombozu tanısını destekleyen yararlı bir biyobelirteç olabileceğini göstermektedir.

Anahtar sözcükler: Akut derin ven trombozu, hemogram parametreleri, trombosit sayıs1, trombosit/lenfosit oran1. 
Deep vein thrombosis (DVT) is defined as the formation of a thrombus mostly in the lower extremity veins leading to occlusion or interruption of the blood flow. It is the third most frequent cardiovascular disorder following coronary artery disease and stroke. ${ }^{[1]}$ If left undiagnosed and untreated promptly, it may lead to serious morbidity and mortality.

Although medical and surgical treatment modalities have evolved in recent years, DVT still poses a potential problem, as it is associated with various clinical entities such as chronic venous insufficiency, phlegmasia cerulea dolens, venous gangrene, and pulmonary thromboembolism which all can have severe consequences. ${ }^{[2-5]}$ Hereditary or acquired tendency to thrombosis, hypercoagulability, venous stasis, endothelial damage, and inflammation are the main factors which play a role in the etiopathogenesis of DVT.

In cases of DVT, inflammatory response occurs with the increase in several biomarkers in the blood such as C-reactive protein (CRP) and interleukins. ${ }^{[6]}$ In addition to these known markers, some routine complete blood count (CBC) parameters such as the mean platelet volume (MPV) and red cell distribution width (RDW) have been studied as the inflammatory indicators in patients with DVT. ${ }^{[7-9]}$ On the other hand, novel and promising inflammatory biomarkers derived from CBC tests such as platelet-to-lymphocyte ratio (PLR) and neutrophil-to-lymphocyte ratio (NLR) have recently been investigated in various diseases, and gained an increasing popularity in many medical societies worldwide. ${ }^{[10-14]}$ In accordance with the role of the inflammatory process, these aforementioned novel markers have been studied in vascular diseases as well, although studies investigating both PLR and NLR in patients with DVT are scarce. In addition, previous studies in the literature have often addressed into particular CBC parameters and there is no comprehensive study investigating all $\mathrm{CBC}$ parameters in DVT patients.

In the present study, we aimed to investigate most of the routine CBC parameters as well as the novel inflammatory biomarkers such as PLR and NLR in patients with acute lower extremity DVT and to evaluate the clinical relevance of these parameters in this patient population.

\section{PATIENTS AND METHODS}

This retrospective study included a total of 68 patients (29 males, 39 females; mean age
$55.2 \pm 1.6$ years, range, 22 to 80 years) with acute lower extremity DVT and 34 healthy controls (15 males, 19 females; mean age $52.8 \pm 2.5$ years; range, 21 to 77 years) without acute lower extremity DVT between March 2016 and August 2018. The patients with lower extremity DVT presented with the complaints of pain and/or swelling in the leg, and lower extremity venous Duplex ultrasound examination was performed to these patients whose clinical status suggested DVT to confirm the diagnosis. The control group consisted of those who were suspected, but DVT-negative individuals. Demographics and clinical features, and laboratory data of all participants were recorded. Any significant differences, particularly in CBC parameters, between the groups were researched. Data including age, sex, hypertension, diabetes mellitus, hyperlipidemia, and smoking habit were noted. The laboratory data included $\mathrm{CBC}$ parameters such as white blood cell (WBC), hemoglobin (HGB), hematocrit (HCT), platelet (PLT), RDW, MPV, mean corpuscular volume (MCV), neutrophil (NEU), lymphocyte (LYM), NLR, platelet distribution width (PDW), plateletcrit (PCT), PLR, and CRP. Participants under 18 and over 80 years, those having a history of previous DVT or using oral anticoagulants, and those with hematological malignancies, severe chronic heart, lung, liver or kidney disease, active infection and primary immunodeficiency were excluded from the study. A written informed consent was obtained from each participant. The study protocol was approved by the Bolu Abant İzzet Baysal University Clinical Researches Ethics Committee. The study was conducted in accordance with the principles of the Declaration of Helsinki.

Peripheral venous blood samples were obtained from each participant included in the study, and the samples were placed into sterile tubes containing a standard amount of anticoagulant. To detect the results of CBC parameters, the blood samples were studied in an automatic CBC analysis device (Beckman Coulter Inc., CA, USA) within one hour after the samples were taken. Original kits of the manufacturer were utilized in the laboratory assays.

\section{Statistical analysis}

Due to the retrospective design of the study, only patients who were admitted to our hospital with a certain date were included. Therefore, we performed a post-hoc compute achieved power analysis and, in the presence of the aforementioned sample size, the power (1- $\beta$ err prob) was found to be 0.88 with an effect size of 0.5 . 
Statistical analysis was performed using the IBM SPSS for Windows version 20.0 software (IBM Corp., Armonk, NY, USA). Normality of the continuous variables was assessed using the Shapiro-Wilk test. The normally distributed variables were analyzed using the independent samples t-tests. The MannWhitney $U$ test was used for non-normally distributed continuous variables. Categorical variables were analyzed using the chi-square with Fisher's exact correction, where applicable. Logistic regression analysis was performed to identify significant predictors of acute DVT and the odds ratio (OR) for each possible variable was calculated after adjusting for the effects of the other variables. Continuous variables were presented in mean \pm standard deviation and median (min-max), while categorical variables were presented in number and frequency. A $p$ value of $<0.05$ was considered statistically significant.

\section{RESULTS}

There was no significant difference in the age and gender. However, the mean RDW and PLT levels were found to be significantly higher in the patients with DVT (for DVT group vs. control group; mean RDW $17.1 \pm 0.3$ vs. $16.3 \pm 0.2, \mathrm{p}=0.028$; mean PLT $298.1 \pm 12.9$ vs. $251.2 \pm 16.0, \mathrm{p}=0.031)$. Other compared laboratory parameters were found to be statistically similar between the groups. The results of univariate analysis of the variables for the control and DVT groups are presented in Table 1.

Logistic regression analysis results are summarized in Table 2. After controlling for other variables, increased PLT count and PLR were found to be the significant predictors of the diagnosis of DVT. The risk of DVT increased by $15 \%$ with one unit increase in the PLT $(\mathrm{OR}=1.015$; $95 \%$ CI: 1.003-1.027; $\mathrm{p}=0.014$ ), while the same risk increased by $14.8 \%$

Table 1. Univariate analysis for control and deep vein thrombosis groups

\begin{tabular}{|c|c|c|c|c|c|c|c|}
\hline \multirow[b]{2}{*}{ Variables } & \multicolumn{3}{|c|}{ Control group $(\mathrm{n}=34)$} & \multicolumn{3}{|c|}{ Deep vein thrombosis group $(n=68)$} & \multirow[b]{2}{*}{$p$} \\
\hline & $\mathrm{n}$ & $\%$ & Mean \pm SD & $\mathrm{n}$ & $\%$ & Mean \pm SD & \\
\hline Age (year) & & & $52.8 \pm 2.5$ & & & $55.2 \pm 1.6$ & 0.425 \\
\hline Gender & & & & & & & 0.888 \\
\hline Male & 15 & 44.1 & & 29 & 42.6 & & \\
\hline Female & 19 & 55.9 & & 39 & 57.4 & & \\
\hline Hypertension & 9 & 26.5 & & 12 & 17.6 & & 0.299 \\
\hline Diabetes mellitus & 3 & 8.8 & & 9 & 13.2 & & 0.746 \\
\hline Hyperlipidemia & 6 & 17.6 & & 15 & 22.1 & & 0.603 \\
\hline Smoking & 11 & 32.4 & & 13 & 19.1 & & 0.137 \\
\hline C-reactive protein (mg/dL) & & & $6.6 \pm 1.0$ & & & $13.0 \pm 2.8$ & 0.087 \\
\hline Hemoglobin $(\mathrm{g} / \mathrm{dL})$ & & & $13.2 \pm 0.4$ & & & $12.6 \pm 0.2$ & 0.141 \\
\hline Hematocrit (\%) & & & $40.1 \pm 1.1$ & & & $39.8 \pm 1.6$ & 0.281 \\
\hline Mean corpuscular volume (fL) & & & $85.2 \pm 0.9$ & & & $86.6 \pm 0.8$ & 0.307 \\
\hline Red cell distribution width (\%) & & & $16.3 \pm 0.2$ & & & $17.1 \pm 0.3$ & 0.028 \\
\hline White blood cell $\left(\times 10^{9} / \mathrm{L}\right)$ & & & $8.4 \pm 0.5$ & & & $9.0 \pm 0.4$ & 0.348 \\
\hline Platelet $\left(\times 10^{9} / \mathrm{L}\right)$ & & & $251.2 \pm 16.0$ & & & $298.1 \pm 12.9$ & 0.031 \\
\hline Neutrophil (×109/L) & & & $67.9 \pm 1.8$ & & & $70.2 \pm 1.3$ & 0.324 \\
\hline Lymphocyte $\left(\times 10^{9} / \mathrm{L}\right)$ & & & $17.7 \pm 1.5$ & & & $17.3 \pm 0.9$ & 0.812 \\
\hline Neutrophil-to-lymphocyte ratio & & & $5.3 \pm 0.6$ & & & $5.3 \pm 0.4$ & 0.881 \\
\hline Platelet-to-lymphocyte ratio & & & $18.4 \pm 2.4$ & & & $20.6 \pm 1.4$ & 0.148 \\
\hline Mean platelet volume (fL) & & & $8.0 \pm 0.4$ & & & $8.3 \pm 0.2$ & 0.540 \\
\hline Platelet distribution width (\%) & & & $17.6 \pm 0.2$ & & & $17.9 \pm 0.2$ & 0.348 \\
\hline Plateletcrit $(\%)$ & & & $0.2 \pm 0.0$ & & & $0.2 \pm 0.0$ & 0.140 \\
\hline
\end{tabular}

SD: Standard deviation; Number of normally distributed continuous variables compared using independent samples t-test; Mann-Whitney U test was used for the variables of C-reactive protein, hematocrit, neutrophil-to-lymphocyte ratio, platelet-to-lymphocyte ratio and platelet distribution width; Categorical variables were expressed in frequency $(\%)$ and compared using chi-square tests. 
Table 2. Multivariate analysis results for significant predictor of acute deep vein thrombosis

\begin{tabular}{lccc}
\hline Variables & OR & \%95 CI for OR & $p$ \\
\hline Age & 1.018 & $0.983-1.053$ & 0.320 \\
Hypertension & 0.515 & $0.163-1.630$ & 0.259 \\
Smoking & 0.371 & $0.118-1.167$ & 0.090 \\
Platelet distribution width & 1.181 & $0.933-1.494$ & 0.167 \\
Platelet & 1.015 & $1.003-1.027$ & 0.014 \\
C-reactive protein & 1.028 & $0.981-1.078$ & 0.245 \\
White blood cell & 1.043 & $0.872-1.247$ & 0.647 \\
Neutrophil-to-lymphocyte ratio & 1.573 & $0.972-2.546$ & 0.065 \\
Platelet-to-lymphocyte ratio & 0.852 & $0.731-0.994$ & 0.041 \\
Mean platelet volume & 1.143 & $0.875-1.494$ & 0.327 \\
Platelet distribution width & 1.284 & $0.836-1.972$ & 0.253 \\
Plateletcrit $(\times 1000)$ & 1.036 & $0.977-1.098$ & 0.242 \\
\hline
\end{tabular}

OR: Odds ratio; CI: Confidence interval; The goodness of fit of the model was confirmed by a p-value of 0.705 in the HosmerLemeshow test.

with one unit increase in the PLR (OR=0.852; $95 \%$ CI: 0.731-0.994, $\mathrm{p}=0.041$ ).

\section{DISCUSSION}

In the present study, we investigated most of the routine $\mathrm{CBC}$ parameters as well as the novel inflammatory biomarkers such as PLR and NLR in patients with acute lower extremity DVT. The major finding of this study was that among CBC parameters, not only PLT count, but also PLR were useful biomarkers to support the diagnosis of acute lower extremity DVT, although PLR was not found to be a statistically significant predictor. Although PLR was not a significant variable in the univariate analysis, it was a significant variable in the multivariate logistic regression analysis and, thus, it was considered an important indicator to support the diagnosis. This situation might be clarified by that the effect of PLR may be suppressed by other variables which are included in the multivariate analysis. Indeed, there is no doubt that PLR is directly affected by PLT count, being a significant predictor of DVT diagnosis of increased PLT count leads to that increased PLR is also a significant supporter of DVT diagnosis. Apart from that, another important finding of our study was that RDW levels were statistically significantly higher in the study group than the control group. However, it did reach statistical significance in the multivariate logistic regression analysis; thus, increased RDW level was not considered a significant predictor of DVT diagnosis.
Platelets are mainly responsible for hemostasis and tissue regeneration in the human body. In addition, they play an essential role in thrombus formation. Thromboxane synthesis and release of adhesion molecules secondary to increased PLT count and activity in the blood are considerable etiopathogenetic factors of thrombus formation in the development of venous thrombosis, as well. ${ }^{[15,16]}$ There are many reports indicating that PLT count increases in patients with DVT than those without DVT. ${ }^{[8,17,18]}$ The results of the aforementioned reports are consistent with the results from our study. One of the possible mechanisms of that increase in the PLT count in DVT may be that the levels of inflammatory cytokines in the systemic circulation increase in case of an inflammatory event. These inflammatory cytokines may induce thrombopoiesis in the bone marrow and, thereby, resulting in a more production of PLTs from megakaryocytes. On the contrary, in a study with a relatively large sample size, the authors found no significant difference in the PLT count between the patients with and without DVT. ${ }^{[7]}$ In this study, the authors, for the first time, showed that increased RDW levels were significantly and independently associated with DVT. More interestingly, another study demonstrated that the mean PLT count was significantly lower in the patients with DVT compared to healthy individuals. ${ }^{[9]}$

In recent years, PLR and NLR have become the most popular and valuable CBC parameters as novel inflammatory biomarkers. These parameters are easily calculated by the ratio of PLT and NEU 
counts to lymphocyte count from a simple and inexpensive CBC test. Although both PLR and NLR have been examined and are still being examined in the prediction of a wide range of disease spectrum including many cardiovascular diseases such as congestive heart failure, ${ }^{[10]}$ coronary artery disease, ${ }^{[11]}$ atrial fibrillation, ${ }^{[19]}$ and carotid artery disease,${ }^{[20]}$ there are few studies in the existing literature regarding whether PLR and NLR can be used as predictors in patients with acute lower extremity DVT. Ferroni et al. ${ }^{[21]}$ analyzed the role and clinical importance of PLR and NLR in venous thromboembolism (VTE) risk prediction for ambulatory cancer patients and concluded that only PLR could be used as an independent predictor of a future VTE episode. Similarly, Yang and $\mathrm{Liu}^{[22]}$ investigated that whether PLR was a risk predictor of VTE in cancer patients and revealed that the PLR at the time of cancer diagnosis could be an independent predictor of VTE. These evidences may be considered consistent with our study results; however, the aforementioned studies specifically focused on the prediction of future VTE in patients with cancer. On the other hand, in our study, we performed an analysis to determine independent predictors of acute DVT after comparing all DVT patients (regardless of etiological and comorbid factors) with healthy individuals. However, Yao et al. ${ }^{[23]}$ examined the predictive value of both PLR and NLR for acute DVT development after a specific surgical intervention and reported that neither PLR nor NLR could predict surgery-related DVT accurately. Moreover, in a recent study, the predictive values of PLR and NLR as well as some PLT indices were studied in the patients with acute DVT, consequently only NLR was found to be the independent predictor of DVT. ${ }^{[24]}$

In our opinion, the main strength of the current study is the examination of almost all CBC parameters in patients with DVT and, to the best of our knowledge, this study is the first study to investigate almost all CBC parameters in acute lower extremity DVT. On the other hand, the main limitations of our study are the retrospective nature, relatively small sample size, and single-center cohort study.

In conclusion, our study results suggest that among complete blood count parameters, platelet-tolymphocyte ratio and platelet can be used as significant predictors of acute deep vein thrombosis.

\section{Declaration of conflicting interests}

The authors declared no conflicts of interest with respect to the authorship and/or publication of this article.

\section{Funding}

The authors received no financial support for the research and/or authorship of this article.

\section{REFERENCES}

1. Cohen AT, Agnelli G, Anderson FA, Arcelus JI, Bergqvist D, Brecht JG, et al. Venous thromboembolism (VTE) in Europe. The number of VTE events and associated morbidity and mortality. Thromb Haemost 2007;98:756-64.

2. Yuksel A, Tuydes O. Midterm outcomes of pharmacomechanical thrombectomy in the treatment of lower extremity deep vein thrombosis with a rotational thrombectomy device. Vasc Endovascular Surg 2017;51:301-6.

3. Polat A, Ketenciler S, Yücel C, Boyacioğlu K, Akdemir İ, Kük ZG, et al. Accelerated catheter-directed thrombolytic treatment in deep venous thrombosis: mid-term results. Turk Gogus Kalp Dama 2015;23:485-92.

4. Tok M, Tuydes O, Kan İI, Yuksel A, Yolgösteren A. Our early results for the treatment of acute and subacute iliofemoral deep vein thrombosis with rotational thrombectomy catheter. Turk J Vasc Surg 2014;23:169-75.

5. Dumantepe M, Tarhan A, Kehlibar T, Özler A. Low molecular weight heparin versus oral anticoagulants in the long-term treatment of deep venous thrombosis: Surveillance of thrombus regression. Turk Gogus Kalp Dama 2013;21:69-77.

6. Vazquez-Garza E, Jerjes-Sanchez C, Navarrete A, JoyaHarrison J, Rodriguez D. Venous thromboembolism: thrombosis, inflammation, and immunothrombosis for clinicians. J Thromb Thrombolysis 2017;44:377-385.

7. Cay N, Unal O, Kartal MG, Ozdemir M, Tola M. Increased level of red blood cell distribution width is associated with deep venous thrombosis. Blood Coagul Fibrinolysis 2013;24:727-31.

8. Gulcan M, Varol E, Etli M, Aksoy F, Kayan M. Mean platelet volume is increased in patients with deep vein thrombosis. Clin Appl Thromb Hemost 2012;18:427-30.

9. Cil H, Yavuz C, Islamoglu Y, Tekbas EÖ, Demirtas S, Atilgan ZA, et al. Platelet count and mean platelet volume in patients with in-hospital deep venous thrombosis. Clin Appl Thromb Hemost 2012;18:650-3.

10. Durmus E, Kivrak T, Gerin F, Sunbul M, Sari I, Erdogan O. Neutrophil-to-lymphocyte ratio and platelet-to-lymphocyte ratio are predictors of heart failure. Arq Bras Cardiol 2015;105:606-13.

11. Cho KI, Ann SH, Singh GB, Her AY, Shin ES. Combined usefulness of the platelet-to-lymphocyte ratio and the neutrophil-to-lymphocyte ratio in predicting the long-term adverse events in patients who have undergone percutaneous coronary intervention with a drug-eluting stent. PLoS One 2015;10:e0133934.

12. Pedrazzani C, Mantovani G, Fernandes E, Bagante F, Luca Salvagno G, Surci N, et al. Assessment of neutrophil-tolymphocyte ratio, platelet-to-lymphocyte ratio and platelet count as predictors of long-term outcome after R0 resection for colorectal cancer. Sci Rep 2017;7:1494. 
13. Qin B, Ma N, Tang Q, Wei T, Yang M, Fu H, et al. Neutrophil to lymphocyte ratio (NLR) and platelet to lymphocyte ratio (PLR) were useful markers in assessment of inflammatory response and disease activity in SLE patients. Mod Rheumatol 2016;26:372-6.

14. Yoldas H, Karagoz I, Ogun MN, Velioglu Y, Yildiz I, Bilgi $\mathrm{M}$, et al. Novel mortality markers for critically Ill patients. J Intensive Care Med 2018:885066617753389.

15. Bath PM, Butterworth RJ. Platelet size: measurement, physiology and vascular disease. Blood Coagul Fibrinolysis 1996;7:157-61.

16. Karagoz I, Aktas G, Yoldas H, Yildiz I, Ogun MN, Bilgi $\mathrm{M}$, et al. Association between hemogram parameters and survival of critically Ill patients. J Intensive Care Med 2019;34:511-13.

17. Çalışkan A, Yazıcı S, Karahan O, Demirtaş S, Yavuz $\mathrm{C}$, Güçlü $\mathrm{O}$, et al. The investigation of complete blood counting parameters in deep venous thrombosis. Dicle Med J 2014;41:118-22.

18. Canan A, Halıcioğlu SS, Gürel S. Mean platelet volume and D-dimer in patients with suspected deep venous thrombosis. J Thromb Thrombolysis 2012;34:283-7.

19. Weymann A, Ali-Hasan-Al-Saegh S, Sabashnikov A, Popov AF, Mirhosseini SJ, Liu T, et al. Prediction of new-onset and recurrent atrial fibrillation by complete blood count tests: a comprehensive systematic review with meta-analysis. Med Sci Monit Basic Res 2017;23:179-222.

20. Massiot N, Lareyre F, Voury-Pons A, Pelletier Y, Chikande J, Carboni J, et al. High neutrophil to lymphocyte ratio and platelet to lymphocyte ratio are associated with symptomatic internal carotid artery stenosis. J Stroke Cerebrovasc Dis 2019;28:76-83.

21. Ferroni P, Riondino S, Formica V, Cereda V, Tosetto L, La Farina F, et al. Venous thromboembolism risk prediction in ambulatory cancer patients: clinical significance of neutrophil/lymphocyte ratio and platelet/lymphocyte ratio. Int J Cancer 2015;136:1234-40.

22. Yang W, Liu Y. Platelet-lymphocyte ratio is a predictor of venous thromboembolism in cancer patients. Thromb Res 2015;136:212-5.

23. Yao C, Zhang Z, Yao Y, Xu X, Jiang Q, Shi D. Predictive value of neutrophil to lymphocyte ratio and platelet to lymphocyte ratio for acute deep vein thrombosis after total joint arthroplasty: a retrospective study. J Orthop Surg Res 2018;13:40.

24. Ming L, Jiang Z, Ma J, Wang Q, Wu F, Ping J. Plateletto-lymphocyte ratio, neutrophil-to-lymphocyte ratio, and platelet indices in patients with acute deep vein thrombosis. Vasa 2018;47:143-7. 